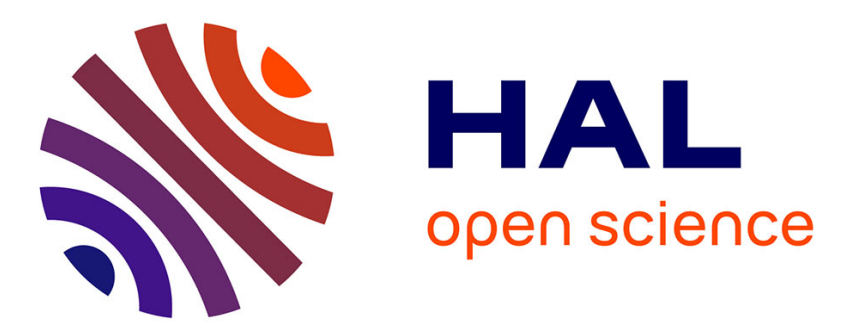

\title{
Culture, territories, and confidence in food. An anthropological view on health in the context of environmental pollution and socio-political tension
}

Anne Bargès

\section{- To cite this version:}

Anne Bargès. Culture, territories, and confidence in food. An anthropological view on health in the context of environmental pollution and socio-political tension. Appetite, 2008, 51 (1), pp 30-33. 10.1016/j.appet.2008.02.003 . halshs-00259396

\section{HAL Id: halshs-00259396 \\ https://shs.hal.science/halshs-00259396}

Submitted on 7 Aug 2012

HAL is a multi-disciplinary open access archive for the deposit and dissemination of scientific research documents, whether they are published or not. The documents may come from teaching and research institutions in France or abroad, or from public or private research centers.
L'archive ouverte pluridisciplinaire HAL, est destinée au dépôt et à la diffusion de documents scientifiques de niveau recherche, publiés ou non, émanant des établissements d'enseignement et de recherche français ou étrangers, des laboratoires publics ou privés. 


\section{Accepted Manuscript}

Title: Culture, territories, and confidence in food. An anthropological view on health in the context of environmental pollution and socio-political tension

Author: Anne Bargès

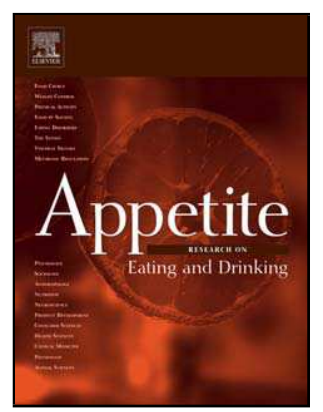

PII:

S0195-6663(08)00081-0

DOI: doi:10.1016/j.appet.2008.02.003

Reference: APPET 577

To appear in:

Received date: $\quad 10-12-2007$

Revised date: $\quad 8-1-2008$

Please cite this article as: Bargès, A., Culture, territories, and confidence in food. An anthropological view on health in the context of environmental pollution and sociopolitical tension, Appetite (2007), doi:10.1016/j.appet.2008.02.003

This is a PDF file of an unedited manuscript that has been accepted for publication. As a service to our customers we are providing this early version of the manuscript. The manuscript will undergo copyediting, typesetting, and review of the resulting proof before it is published in its final form. Please note that during the production process errors may be discovered which could affect the content, and all legal disclaimers that apply to the journal pertain. 
Culture, territories, and confidence in food. An anthropological view on health in the context of environmental pollution and socio-political tension $^{1}$

\section{Anne Bargès}

Department of Sociology, Faculty of Human and Social Sciences, University of Tours,

3 rue des Tanneurs

FR - 37000 Tours, France

anne.barges@ univ-tours.fr 
Culture, territories, and confidence in food. An anthropological view on health in the context of environmental pollution and socio-political tension

\begin{abstract}
Pollutants in the environment as well as potential risks to human health and health policies are leading to profound changes in the food chain. Whether dietary patterns and medical interventions are accepted, depends on the cultural and territorial anchorage of the populations, their socio-cultural past as well as scientific uncertainty and modalities of objectification of social actors. Controversies, debates, and the media influence governance. Local and minority experiences open up global perspectives. This paper focuses on the necessary contextualization of events at the crossroads of various social sciences. The exposure of fish-eating native people to methylmercury in Canada is used as an example.
\end{abstract}

Keywords: Body perceptions; Community values; Risks to public health; Mercury exposure; Diet transformation

\title{
A cross-disciplinary and thematic framework
}

Over the past twenty years ecological changes, intercultural dynamics and concerns in the field of health created a link between various scientific fields such as anthropology/ethnology, environmental sciences, sociology and political sciences. This development reveals that food lies at the heart of a problematic and complex interconnection between the following aspects: the perception of nature and living 
organisms, representations and practices concerning the body and illness, cultural and territorial anchorages, technological and scientific progress, medical regulations, social inequalities in health, et cetera. Fields of research, which do not necessarily belong to the domain of food, therefore are also in need of attention. These are the natural environment and how this environment is imagined or experienced, social actors in this field, and the socio-cultural context. This contextualization is based on the anthropological approach (Hubert, 2001).

Food resources are normally taken into account in the anthropology of illness, which mainly analyses the symbolic meaning of illness (Augé, 1984). These studies were conducted in addition to ethnological research, mainly focussing on traditional and rural communities, in the context of usage and perceptions of the body and its interconnection with nature (Descola, 2002). Based on taxonomic studies of the living world, anthropology constantly emphasises that it is a mistake to consider nature, as in Western societies, as universal and obvious. Recent studies that are based on this assumption analyse the notion of the individual within aboriginal communities in the light of modernity and social changes. These studies are therefore taking place in a more international setting of anthropology (Laugrand, 2007). Territory and its natural resources are traditionally assigned to stability, identity and certainty, and create "trust". These feelings of safety are intensified when populations believe these references to be genuine, immemorial and indestructible. Furthermore, the perception that human beings embody "Earth", identify themselves with it, helps to create these feelings of safety. How can we think and live with these pillars of life being altered and corrupted? Sensitive issues and collective history are put into question. Misunderstandings and tensions have re-appeared on stage. Nevertheless new modes of debating, conciliation and territorial management are also emerging. In 
the framework of the anthropology of contemporary worlds, territories are also considered as a socio-cultural construction often linked to globalisation, technological and economic changes, cultural emancipation, natural upheavals and, subsequently, to health care challenges and governance (Nakashima, 2002; Blaser, 2004).

"Trust" and periods of crisis are also covered in the field of sociology of health and medical anthropology. Sociology of health was developed in France during the 1970s (Herzlich, 1991), with Boltanski's work on the social usage of the body. This field of work was inspired by American sociologists who examined the medical field, especially physicians-patients relationships (I. Zola, G. Friedson, and M. Zborowski). It became evident that the professionals' discourse (forming a gap between the perception and practices of physicians and their patients) could be observed. The question of cultural distance had also been raised. American medical anthropology was developed in particular by Kleinman who looked at health care from three different angles, and separated patients' experiences (illness) and social perceptions (sickness) from a biomedical approach (disease). In French there is only one word, maladie. The aim was to ensure a better adaptation of the health care system to its socio-cultural environment, which would help patients to accept a certain treatment. This implies that the patient trusts the person treating him/her. This trust becomes even stronger if it is a collective feeling that applies to the entire community. The same background makes it easier for the patient to understand biomedical explanations (Western societies) and preventive communication. As it is the case for our example, political and cultural history does not allow for this common background.

In France in the 1980s, some researchers developed also a medical anthropology (Retel-Laurentin, 1987). The applied aspect of anthropology and the fact that 
researches often came from a medical background created conventional and epistemological tensions between the fields of anthropology of illness and ethnology. Fortunately, both fields benefited from these tensions as they mutually embellished each other. The adjective "medical" has progressively been replaced by the anthropology of health, which included both objects and methods of research (Saillant, 2005). Over the last decade, questions on "biopolitic", standardization and inequalities concerning the individual's body and the social body, are covered by the field of "political anthropology of health" (Fassin, 2000). This new field was heavily influenced by Foucault's work and by American post-modern and critical anthropology. The figure of the patient, whose body is used by biomedicine and administrated by the public health care system, is currently taken over from the figure of socio-cultural domination.

Over the past thirty years health has become a continuous challenge because of the trend of medicine becoming increasingly scientific, the medicalization of society and, last but not least, the fact that individuals are becoming increasingly responsible for their own health. Medical findings and progress as well as biotechnological interventions have become commonplace. At the same time, the expectations and disappointment on behalf of the population have increased and go hand in hand with cultural incomprehension and social inequalities. It goes without saying that biomedicine has to standardise data and bring forth the proof of what has been established in order to undertake therapeutic or preventive measures (Bargès, 2001). Its complexity, however, leads to a high level of uncertainty while social changes are increasing, which demands a higher level of certification. This level of uncertainty affects everyday life, especially as environmental risks appear to be longterm issues that are imperceptible. Questions on the origin of food and hazards 
introduced by technology have increased this feeling of insecurity and led to scientific controversies. They now go hand in hand with issues concerning the environment, identity and health. Over the past few years the sociology of sciences thus gained more fields to explore. What at first only seemed to be local or exotic problems that were only affecting minorities revealed themselves as one of the main challenges in globalized societies (pollution, food, health, and sustainable development). There are an increasing number of public debates and mobilisations on these issues (in France for example: GMO, International Thermonuclear Experimental Reactor [ITER], national meeting of cancer patients etc.). In return, these movements favour causes which affect territories as well as communities.

\section{Water pollution, health hazard and diet change - from local to global perspectives}

In the framework of anthropology and sociology, as well as chronic illness, health and science, the example of the events of chronic organic mercury poisoning in Canada will be given. My aim is to show that problems with food, the presence of a specific pollutant in the environment, health policies, and the symbolic weight of the exposure lead to deep physical, cultural and socio-political changes.

Mercury is a heavy metal (such as cadmium or lead), with a pathological risk. It mainly affects the nervous system. Mercury has been commonly used since the practices of alchemists. The widest known example for professional intoxication is the "mad hatter" (see the medical explanation by Hunter \& Russel in 1940). In the twentieth century industrial and chemical developments caused risks of collective exposure. Because of sediments and methylization in water, metal mercury becomes organic and can penetrate through biological barriers (Jensen, 1969). It contaminates 
lakes, rivers and land animals, and it increases biologically through micro organisms. Mercury works its way up through the food chain. As human beings are at the end of the food chain they are at a very high risk. The pollutant is invisible and tasteless as poison. In the 1950s and 1960s the events of Minamata and Agano (Niigata), which were perceived as an epidemic, led to a stronger media coverage of visible and acute stages, and informed the public on direct and congenital risks of chronic exposure. This exposure has mainly been problematic for communities whose diet is very much based on fish and not very diversified. For the last thirty years, stages of exposure to methylmercury $(\mathrm{MeHg})$, which were less intensive but of a longer duration, have been described throughout the entire world ${ }^{2}$. Minamata has always been used as a reference.

From the late 1960s onwards, Canadian Authorities issued warnings on the general pollution due to sediments in the region of the Great Lakes and some rivers in Ontario and Quebec. This pollution affected fishing inland waters and especially the fish at the end of food chain (pike, walleye and whitefish). A similar case could later on be observed at James Bay with the great "reservoirs" of the hydroelectric project after impounding. The affected regions are largely located in what is called a Boreal region, where water is of a greater presence than elsewhere. This element has taken up a symbolic value in Canada's national construction as it is, on the one hand, associated to pure and original nature that needs to be preserved and serves as a place for well being and tourism. On the other hand, water is the driving force behind industrial exploitation and contributes to economic growth. It is as if the "last frontier" with "wilderness" is being pushed back (Roué, 2003).

The polluted waters particularly affected two aboriginal populations, one in the northwest of Ontario, the Ojibway communities (Anishinaabe) of Grassy Narrows and 
White Dog, which are living in the northwest of Québec, as well as the Cree communities in the region of Mistassini and Noranda. In both cases, the pollution came from Chlorate-alkali factories that belonged to major industrial trusts producing pulp $^{3}$. The context was somewhat different. As their land is accessible by roads, the Ojibway community has been exposed to non-native lifestyle for a much longer time than the Crees. The former experienced industrial exploitation of natural resources instead of tourism. In 1945 the natives ran the majority of commercial fishing companies, and the numerous fishing camps for tourists were their primary source of income. White Dog and Grassy Narrows communities had already suffered from two relocations that took place in 1956 and 1963 and brought about social and economic disruptions. Their lifestyle had been changing, but hunting and fishing remained important. In this province American Indian militancy emerged during these years. The territories of the Crees in Quebec, who mainly secured their livelihood by means of hunting and fishing, were not connected to roads for a very long time. Contact with the administration favouring settlement was only made in the 1970s, when projects of hydroelectric installations were carried out in the region. The dietary habits of those two communities are still very much based on fish.

Anthropologists ${ }^{4}$ have shown that the relationship with nature is vital. The human being is placed into animistic and holistic worlds, and intimate links exist with the entire ecosystem. The taxonomy of Algonquian distinguishes between forest animals, pillars of life and other animals. Hunting and fishing is a form of establishing mutual personal relationships between humans and animals. These animals contribute to the social tie, the stability of the group as well as to cultural stability (Feit, 2000).

Disrespecting certain ties with nature is therefore considered as asocial behaviour (Bousquet, 2002), and everybody needs to take on responsibility for the balance of 
his/her Earth and his/her people. The territory is perceived as a calendar and coordinates these ties. The land of ancestors has also become a place of socioeconomic relegation and has therefore reinforced the phenomenon of the inner circle Fish such as pike and walleye bream are some of the main ingredients in the traditional cuisine of these communities. Their style of cooking used to be rich in proteins, using only very little sugar or fat. An ideal meal (i.e., the most traditional and therefore the most valued meal) consists of game or fresh-water fish. Traditional meals favour commensality within the group. These meals are referred to as "genuine food", which the community is confident in and which is described with native words. It is a pure form of food, with clear origins whose genesis can be traced back. European food means alteration or poisoning. The construction of the native body has a conflict-related relationship with western society, and in this context being disgusted means to resist. There is a political use of the body and food ${ }^{5}$. However, inclusive food as an identity sign is also transforming. Flour and sugar have been appropriated for long. Even alcohol, which had been forbidden for a long time, appeared in the middle of the $20^{\text {th }}$ century as a conquest (Roy, 2002).

Scientific discourse and its uncertainties, the epidemiologic studies and their social dimension will be used for describing the framework mentioned above. Looking at these factors will enable to establish why the population accepts or refuses certain proposals. After the first samples were taken in Canadian waters, an analysis of MeHg took place in the Ojibway community in 1970 and in the community of the Crees in 1971. As a result commercial fishing was banned in Ontario. The consequences were rather brutal and led to the last resort, which was described as 'fishing for fun' (throwing the catch directly back into the water). This ban had catastrophic consequences for the local economy. Furthermore, it had an extremely 
negative impact on the livelihood of native peoples, and reinforced socio-economic inequalities as well as the feeling of cultural domination. In Quebec commercial fishing was partially banned. The late release of the results (1975) of earlier studies and the lack of transparency and of quality, as well as centralised and badly adapted organisations, made the situation even worse. Sanitary policies were following models that are based on the individual's responsibility, while the conception of indigenous communities is much larger that the individual's body. The National Indian Brotherhood commissioned a Japanese expertise that seemed more credible. It confirmed cases of the Minamata disease (Harada, 1976) in Ontario. Mercury therefore became the symbol of an ethnocide, i.e. an identity argument.

While scientific and medical argumentation remained complex, a climate of suspicion was created by the mediatization of the issue. The physiopathology of Mercury and, even more so, the link between doses and effect are not very well known amongst a sparsely spread population that is exposed to lower levels of $\mathrm{MeHg}$ and for a longer duration (as opposed to Minamata). Pregnant women were exposed with after-effects for their children. In clinical tests the neurological symptomatology in this social environment might become part of other aetiologies. The only possible medical intervention is preventive. The patient has to undergo a chelation therapy to bind $\mathrm{MeHg}$ and avoid ingesting the product. These conditions amplified the symbolic value of this phenomenon and made it even more difficult to handle the situation. From 1975 onward, boards monitoring the study of mercury ${ }^{6}$ were being created. Their potential to take action varied from province to province. Studies on the social impact will be carried out and allow for compensations.

The James Bay and Northern Quebec Agreement of 1975, other agreements on mercury and, finally, 'The Peace of the Braves' in 2002 brought about considerable 
change and means for the Cree, when it came to their governance ${ }^{7}$ on development in the fields of education, social and sanitary issues as well as tourism. As opposed to Ontario these agreements have led to a better coordination of studies on mercury as perceptions and have led to an increased consideration of risk-benefit analysis. The social and sanitary impact (diabetes, obesity, and cardiovascular pathologies) of the advocated measures needs to be observed. Communication on nutrition, which is used as a form of prevention, is subtler and recommends eating only rarely some types of fish while, on the other hand, respecting the traditional $\operatorname{diet}^{8}$. This coordination has improved the compliance and reduced the mercury rates while emphasising preventive measures. In Canada, this native diet is gaining increasing popularity due to its natural and dietary virtues. The mediatization of this diet could be compared to the popularity of the Mediterranean diet in Europe. This could be another argument defending native values and territories. These events have had an impact on people's minds, practices, science and politics. They have contributed to Pan-Canadian and international awareness of a global ${ }^{9}$ and permanent problem. Other cases of water pollution causing risks for food are therefore seen in a different light.

\section{References}

Augé, M. \& Herzlich Cl. (1984). Le sens du mal: Anthropologie, histoire, sociologie de la maladie. Paris : Archives Contemporaines.

Bargès, A. (1990). L'exposition chronique au mercure organique au Canada : approche anthropologique. Nancy : Nancy Université SCD. 
Bargès, A. (2001). Anthropologie et sociologie associées au domaine de la maladie et de la médecine. In P. Bagros et al. (Eds). Introduction aux sciences humaines en médecine (pp.131-205). Paris: Ellipses.

Blaser, M., Feit, H.A. \& McRae, G. (Eds). (2004). In the way of development. Indigenous peoples, life projects and globalization. London : ZedBooks.

Delavigne, A. E. (2001). Aliments purs, aliments sain(t)s, la dimension identitaire des peurs alimentaires au Danemark. Anthropology of food. Online Journal http://aof.revues.org

Bousquet, MP. (2002). Les Algonquins ont-ils toujours besoin des animaux indiens? Réflexions sur le bestiaire contemporain. Théologiques 1, 63-87.

Descola, P. (2002). L'anthropologie de la nature, Annales. Histoire, Sciences Sociales 1, 8-37.

Dumont, Ch. (1987). Programme de surveillance de l'exposition au mercure methylique. Rapport Conseil Cri de la Santé et des Services Sociaux, DSC Hopital Général de Montréal.

Fassin, D. (2000). Politiques de la vie et politiques du vivant. Pour une anthropologie de la santé. Anthropologie et Sociétés 1, 95-116.

Feit, H.A. (2000). Les animaux comme partenaires de chasse. Réciprocité chez les Cris de la Baie James. Terrains 134, 123-142.

Harada, M. et al (1976). Epidemiological and clinical study and historical background of mercury pollution on Indian reservations in Norwestern Ontario, Canada. Bulletin of the Institute of Constitutional Medicine (Kunamoto university) 26, $169-184$.

Herzlich, C. \& Pierret, J. (1991). Malades d'hier, malades d'aujourd'hui, de la mort collective au devoir de guérison. Paris : Payot. 
Hubert, A. (2001). Alimentation et Santé : la Science et l'imaginaire. Anthropology of Food. Online Journal <http://aof.revues.org >.

Jensen, S. \& Jernelov, A. (1969). Biological methylation of mercury in aquatic organisms. Nature 223, 753-754.

Laugrand, F.B. \& Oosten, J.G. (Eds). (2007). Nature of Spirits in Aboriginal Cosmologies. Montréal: Presses de l'Université de Laval.

Nakashima, D. \& Roué, M. (2002). Indigenous knowledge, peoples and sustainable practice. In Munn, T. (Ed), Encyclopedia of Global Environmental Change (pp.314-324). Chichester: John Wiley \& Sons.

Retel Laurentin, A. (Ed.) (1987). Etiologie et perception de la maladie dans les sociétés modernes et traditionnelles. Paris: L’Harmattan.

Roué, M. (2003). ONG environnementalistes américains et Indiens Cris? Revue internationale des sciences sociales 178, 679-687.

Roy, B. (2002). Sang sucré, pouvoirs codés et médecine amère. Diabète et processus de construction identitaire. Montréal: Presses de l'Université de Laval.

Saillant, F. \& Genest, S. (Eds). (2005). Anthropologie médicale. Ancrages locaux, défis globaux. Québec: Presses de l'Université Laval.

Yager, JW. \& Horvat, M. (2006). Preface: Recent Findings in Mercury Health Effects. Environmental Health Perspectives 2, 289.

\footnotetext{
${ }^{1}$ I would like to thank Mme Anna-Lena Schockenhoff for proofreading this text.

${ }^{2}$ Fishing people: Sweden, Peru, New Zealand, Canada, USA, Brazil, French Guyana (mining-gold products) and China. Accidental exposure to chemical products used in agriculture: Mexico, Guatemala, and Iraq.
} 
${ }^{3}$ In North - West Ontario, Dryden Chemicals Ltd. of the Reed Paper Company (1960 and 1962) has stopped their emissions in 1975; in North - West Québec, Domtar Chemical Ltd. was active from 1961 to 1978.

${ }^{4}$ See A.I. Hallowell, E. Desveaux, E. Navet, H. Feit, M.P. Bousquet, M. Roué et cetera; linked with mercury events, see A. Shkilnyk, P. Usher or M. Weinstein.

${ }^{5}$ See defensive reactions in Denmark (Delavigne, 2001).

${ }^{6}$ Ontario: Mercury Task Force (1975), Mercury Disability Board (1986), compensating patients. Quebec: le Comité d'étude et d'intervention sur le mercure (Barbeau-Nantel, 1975); since 1982 CBHSS Cree Board of Health \& Social Services of James Bay (Montreal).

${ }^{7}$ The Ojibway community in Ontario has not acquired this decision-making power. For groups of Amerindians in French Guyana, who have equally been exposed and are faced with centralised administration, it is worse.

${ }^{8}$ See research by the Centre for Indigenous People Nutrition and Environment (Montréal), http://www.mcgill.ca/cine/.

${ }^{9}$ See The annual International Conference on Mercury As a Global Pollutant ; the Global Agreement on Mercury Pollution Focus of International Meeting (Bangkok/Nairobi, 12 November 2007). 